\title{
Minocycline Enhances the Effectiveness of Nociceptin/Orphanin FQ during Neuropathic Pain
}

\author{
Katarzyna Popiolek-Barczyk, ${ }^{1}$ Ewelina Rojewska, ${ }^{1}$ Agnieszka M. Jurga, \\ Wioletta Makuch, ${ }^{1}$ Ferenz Zador, ${ }^{2}$ Anna Borsodi, ${ }^{2}$ Anna Piotrowska, ${ }^{1}$ \\ Barbara Przewlocka, ${ }^{1}$ and Joanna Mika ${ }^{1}$ \\ ${ }^{1}$ Department of Pain Pharmacology, Institute of Pharmacology, Polish Academy of Sciences, \\ 12 Smetna Street, 31-343 Cracow, Poland \\ ${ }^{2}$ Institute of Biochemistry, Biological Research Center, Hungarian Academy of Sciences, \\ Temesvári krt 62 Street, Szeged 6726, Hungary
}

Correspondence should be addressed to Joanna Mika; joasia272@onet.eu

Received 14 May 2014; Accepted 1 August 2014; Published 3 September 2014

Academic Editor: Livio Luongo

Copyright (C) 2014 Katarzyna Popiolek-Barczyk et al. This is an open access article distributed under the Creative Commons Attribution License, which permits unrestricted use, distribution, and reproduction in any medium, provided the original work is properly cited.

\begin{abstract}
Nociceptin/orphanin FQ (N/OFQ) antinociception, which is mediated selectively by the N/OFQ peptide receptor (NOP), was demonstrated in pain models. In this study, we determine the role of activated microglia on the analgesic effects of N/OFQ in a rat model of neuropathic pain induced by chronic constriction injury (CCI) to the sciatic nerve. Repeated 7-day administration of minocycline $(30 \mathrm{mg} / \mathrm{kg}$ i.p.), a drug that affects microglial activation, significantly reduced pain in CCI-exposed rats and it potentiates the analgesic effects of administered N/OFQ (2.5-5 $\mu \mathrm{g}$ i.t.). Minocycline also downregulates the nerve injury-induced upregulation of NOP protein in the dorsal lumbar spinal cord. Our in vitro study showed that minocycline reduced NOP mRNA, but not protein, level in rat primary microglial cell cultures. In $\left[{ }^{35} \mathrm{~S}\right] \mathrm{GTP} \gamma \mathrm{S}$ binding assays we have shown that minocycline increases the spinal N/OFQ-stimulated NOP signaling. We suggest that the modulation of the N/OFQ system by minocycline is due to the potentiation of its neuronal antinociceptive activity and weakening of the microglial cell activation. This effect is beneficial for pain relief, and these results suggest new targets for the development of drugs that are effective against neuropathic pain.
\end{abstract}

\section{Introduction}

Neuropathic pain is a common consequence of nervous tissue damage. The mechanisms underlying neuropathy still remain unclear, and the currently available drugs are frequently ineffective, making treatment a major clinical challenge $[1,2]$. Nociceptin/orphanin FQ (N/OFQ) acts through the N/OFQ peptide receptor (NOP) [3] and can change responsiveness to painful stimuli in several models of pain [4-6]. Proand antinociceptive effects of N/OFQ have been reported in a variety of animal models depending on the route of administration. Intracerebroventricular (i.c.v.) administration was found to display hyperalgesic effects $[3,7,8]$, which were mediated by NOP, as these effects are not present in NOP-knockout mice [9]. In contrast, N/OFQ administered intrathecally (i.t.) has been generally found to produce antinociceptive responses $[4,5,10-16]$.

The role of N/OFQ in the development of neuropathic pain has been extensively studied. In recent studies, it has been found that the N/OFQ system influences glial cell functions [17-21] and now it is considered if neuroimmune interaction may be one of the mechanisms of its antinociceptive properties. We have shown that microglia are the glial cell type to be activated in response to peripheral nerve injury and that this activation is in parallel with changes in neuropeptide systems involved in nociceptive transmission (proenkephalin, prodynorphin, and pronociceptin) [17]. Biochemical studies revealed the presence of N/OFQ and its receptor in the CNS and peripheral tissues, particularly in regions associated with nociceptive pathways [22-28]. 
The NOP was demonstrated to be expressed not only on neurons but also on astrocytes and microglia [20, 21], which further suggest the involvement of these cells in the modulation of N/OFQ system. Fu et al. have [20] shown that spinal cord astrocyte activation and in vitro cytokine production by those glial cells are attenuated by N/OFQ through the astrocytic NOP. It was shown that LPS-induced IL-1 $\beta$ gene expression was reduced by N/OFQ in cultured primary microglia, but it was enhanced in neuronal cultures [21]. The regulatory effects of N/OFQ on glia-derived cytokines suggest that the action of the N/OFQ system is dependent on glial cell activation in the CNS.

The aim of the present study was to determine the role of activated microglia in the analgesic effects of N/OFQ in a rat model of neuropathic pain (achieved by chronic constriction injury to the sciatic nerve, CCI). In our studies, we used minocycline, a well-characterized drug for inhibiting microglial activation [29-32], viability, and migration $[33,34]$. Minocycline $(30 \mathrm{mg} / \mathrm{kg}$ ) was intraperitoneally (i.p.) administered preemptively $16 \mathrm{~h}$ and $1 \mathrm{~h}$ before CCI and then twice daily for 7 days. On day 7 after injury, vehicle- or minocycline-treated CCI-exposed rats received intrathecally (i.t.) $\mathrm{N} / \mathrm{OFQ}$, and we examined the analgesic effects using von Frey and cold plate tests. In our biochemical studies, we analyzed molecular changes in mRNA and protein levels of the NOP in the dorsal horn of the lumbar spinal cord at day 7 after injury in vehicle- or minocycline-treated CCI-exposed rats using qRT-PCR and Western blot analysis, respectively. Additionally, using primary cultures of rat microglia, we investigated the effects of minocycline on mRNA and protein levels of NOP. We also investigated the effects of minocycline on NOP signaling in the spinal cord of the vehicle- or minocycline-treated CCI-exposed rats using a functional $\left[{ }^{35} \mathrm{~S}\right] \mathrm{GTP} \gamma \mathrm{S}$ binding assay.

\section{Methods}

2.1. Animals. Male Wistar rats (200-350 g) were housed in cages that were lined with sawdust under a standard $12 / 12 \mathrm{~h}$ light/dark cycle (lights on at 08:00 h) with food and water available ad lib. Care was taken to reduce the number of animals used. All experiments were approved by the local bioethics committee (Cracow, Poland) and were performed according to the recommendations of IASP [35], ARRIVE guidelines [36], and the NIH Guide for the Care and Use of Laboratory Animals.

2.2. Surgical Preparations. Chronic constriction injury (CCI) was produced in rats according to Bennett and Xie [37], by tying four ligatures around the sciatic nerve under sodium pentobarbital anesthesia (60 mg/kg; i.p.). The biceps femoris and the gluteus superficialis were separated, and the right sciatic nerve was exposed. The ligatures $(4 / 0$ silk) were tied loosely around the nerve distal to the sciatic notch with 1- $\mathrm{mm}$ spacing until they elicited a brief twitch in the respective hind limb. After the surgery, all rats developed long-lasting neuropathic pain symptoms such as allodynia and hyperalgesia. Because we have shown in earlier studies that there are no differences between the nociceptive responses of naive and sham animals [38], we used naïve animals for the behavioral experiments in the present study.

2.3. Intrathecal (i.t.) Injection. Rats were prepared for intrathecal (i.t.) injection by implanting catheters according to the method of Yaksh and Rudy [39] under pentobarbital $(60 \mathrm{mg} / \mathrm{kg}$ i.p.) anesthesia. The intrathecal catheter consisted of polyethylene tubing that was $12 \mathrm{~cm}$ long (PE 10, Intramedic; Clay Adams, Parsippany, NJ) with an outside diameter of $0.4 \mathrm{~mm}$ and a dead space of $10 \mu \mathrm{L}$ that had been sterilized by immersion in $70 \%(\mathrm{v} / \mathrm{v})$ ethanol and been fully flushed with sterile water before insertion. Rats were placed on a stereotaxic table (David Kopf Instruments, Tujunga, CA), and an incision was made in the atlantooccipital membrane. The catheter $(7.8 \mathrm{~cm}$ of its length) was carefully introduced into the subarachnoid space at the rostral level of the spinal cord lumbar enlargement (L4-L5). After the implantation, the first injection of $10 \mu \mathrm{L}$ of water was performed slowly, and the catheter was tightened. After catheter implantation, the rats were monitored for physical impairments. Those showing motor deficits (ca 5\%) were excluded from further study. Animals were allowed a minimum of 1 week to recover after the surgery before the experiment began. Water for injection or respective drugs were delivered slowly (1-2 min) in a volume of $5 \mu \mathrm{L}$ through the i.t. catheter and were followed by $10 \mu \mathrm{L}$ of water, which flushed the catheter.

\subsection{Behavioral Tests}

2.4.1. Tactile Allodynia (Von Frey Test). Allodynia was measured in rats subjected to CCI by the use of an automatic von Frey apparatus (Dynamic Plantar Aesthesiometer cat. no. 37400, Ugo Basile, Italy). Rats were placed in plastic cages with a wire net floor $5 \mathrm{~min}$ before the experiment. The von Frey filament (up to $26 \mathrm{~g}$ ) was applied to the midplantar surface of the hind foot, and measurements were taken automatically [40].

2.4.2. Hyperalgesia (Cold Plate Test). Hyperalgesia was assessed using the cold plate test (Cold/Hot Plate Analgesia Meter no. 05044 Columbus Instruments, USA) as has been described previously $[40,41]$. The temperature of the cold plate was maintained at $5^{\circ} \mathrm{C}$, and the cut-off latency was $30 \mathrm{~s}$. The rats were placed on the cold plate, and the time until lifting of the hind foot was recorded. The injured foot was the first to react in every case.

2.5. Drug Administration. The chemicals used in this study and their sources were as follows: N/OFQ (cat. no. 0910, TOCRIS, UK), and minocycline hydrochloride (cat. no. M9511, Sigma-Aldrich, USA). Minocycline (30 mg/kg; i.p.) was dissolved in sterile water and preemptively administered intraperitoneally $16 \mathrm{~h}$ and $1 \mathrm{~h}$ before CCI and then twice daily for 7 days. This method of minocycline administration was used throughout the work and is referred to in the text as "repeated administration". The control groups received a vehicle (water for injection) according to the same schedule. 
One hour after the last morning of minocycline or vehicle administration on day 7 after CCI, N/OFQ $(2.5$ and $5 \mu \mathrm{g} / 5 \mu \mathrm{L})$ or a vehicle was i.t. injected. After vehicle or N/OFQ administration the von Frey test (20 and 40 min later) and cold plate tests (30 and 50 min later) were performed.

2.6. Microglial Cell Cultures and Treatments. Primary cultures of microglial cells were prepared from 1-day-old Wistar rat pups as previously described [42]. Briefly, cells were isolated from the rats' cerebral cortices and were plated at a density of $3 \times 10^{5}$ cells $/ \mathrm{cm}^{2}$ in a culture medium that consisted of DMEM/Glutamax/high glucose (Gibco, USA) supplemented with heat-inactivated $10 \%$ fetal bovine serum (Gibco, USA), $100 \mathrm{U} / \mathrm{mL}$ penicillin, and $0.1 \mathrm{mg} / \mathrm{mL}$ streptomycin (Gibco, USA) on poly-L-lysine coated $75 \mathrm{~cm}^{2}$ culture flasks maintained at $37^{\circ} \mathrm{C}$ and $5 \% \mathrm{CO}_{2}$. The culture medium was changed after 4 days. The loosely adherent microglial cells were recovered after 9 days by mild shaking and centrifugation. Microglial cells were suspended in a culture medium and plated at a final density of $2 \times 10^{5}$ cells onto 24 well plates and $1.2 \times 10^{6}$ cells onto 6 -well plates. Adherent cells were incubated for $48 \mathrm{~h}$ in a culture medium before being used for the analyses. Cell specificity was determined in cultures of primary microglia by Western blot assay using an antibody against OX-42 (a microglial marker) and qRT-PCR using primers for $\mathrm{Clq}$ (a microglial marker) and GFAP (an astrocyte marker). The homogeneity of microglial population was kept on high level (more than 95\% positive for OX-42 and C1q), and our homogeneity was similar to those published by Mika et al. [41]. Primary microglial cell cultures were treated with minocycline $(10 \mu \mathrm{M})$ or vehicle (water) for $6 \mathrm{~h}$ for mRNA analysis and for $24 \mathrm{~h}$ for protein analysis.

2.7. qRT-PCR Analysis of Gene Expression. Ipsilateral dorsal rat spinal cords (L4-L6) were collected 7 days after injury, $4 \mathrm{~h}$ after last morning minocycline treatment. Total RNA was extracted according to the method described by Chomczynski and Sacchi [43] using TRIzol reagent (Invitrogen) as previously described [6]. RNA concentration was measured using a NanoDrop ND-1000 Spectrometer (NanoDrop Technologies). Reverse transcription was performed on $500 \mathrm{ng}$ (from cell cultures) or $1000 \mathrm{ng}$ (from tissue) of total RNA using Omniscript reverse transcriptase (Qiagen Inc.) at $37^{\circ} \mathrm{C}$ for 60 min. cDNA was diluted $1: 10$ with $\mathrm{H}_{2} \mathrm{O}$. qRT-PCR was performed using Assay-On-Demand TaqMan probes according to the manufacturer's protocol (Applied Biosystems) and run on a Real-Time PCR iCycler (BioRad, Hercules, CA, USA). Rn01527838_g1 (Hprt) and Rn00440563_m1 (Orl1) were used as TaqMan primers and probes. The expression of HPRT (a housekeeping gene) was quantified to control group for variation in cDNA amounts. Cycle threshold values were calculated automatically by iCycler IQ 3.0 software with default parameters. Abundance of RNA was calculated as $2^{\text {-(threshold cycle) }}$.

2.8. Western Blot Analysis. Ipsilateral dorsal rat spinal cords (L4-L6) were collected for protein analyses at day 7 after injury, $6 \mathrm{~h}$ after the last morning minocycline treatment.
Cell and tissue lysates were collected in RIPA buffer with a protease inhibitor cocktail and cleared by centrifugation $\left(14000 \times \mathrm{g}\right.$ for $\left.30 \mathrm{~min}, 4^{\circ} \mathrm{C}\right)$. Samples containing $15 \mu \mathrm{g}$ (cells lysates) and $20 \mu \mathrm{g}$ (tissue lysates) of protein were heated in a loading buffer $(50 \mathrm{mM}$ Tris- $\mathrm{HCl}, 2 \% \mathrm{SDS}, 2 \% \beta$ mercaptoethanol, $4 \%$ glycerol, and $0.1 \%$ bromophenol blue) for $8 \mathrm{~min}$ at $98^{\circ} \mathrm{C}$ and resolved on $10-20 \%$ Criterion TGX precast polyacrylamide gels. Following gel electrophoresis, the proteins were transferred to Immune-Blot PVDF membranes (Bio-Rad) with semidry transfer $(30 \mathrm{~min}, 25 \mathrm{~V})$. The membranes were blocked for $1 \mathrm{~h}$ using $5 \%$ nonfat dry milk (Bio-Rad) in Tris-buffered saline with $0.1 \%$ Tween 20 (TBST), washed in TBST, incubated overnight at $4^{\circ} \mathrm{C}$ with primary antibodies (rabbit polyclonal anti-OPRL1, 1:600; rabbit polyclonal anti-IBA1, 1:500, ProteinTech), and incubated for $1 \mathrm{~h}$ at RT with a secondary goat polyclonal antibody that had been conjugated to horseradish peroxidase (goat anti-rabbit IgG, 1:5000, BioRad). Both primary and secondary antibodies were diluted in solutions from SignalBoost Immunoreaction Enhancer Kit (Merck Millipore). Membranes were washed $2 \times 2 \mathrm{~min}$ and $3 \times 5 \mathrm{~min}$ with TBST. Immunocomplexes were detected using a Immun-Star HRP Chemiluminescent Substrate Kit (BioRad) and visualized using a Fujifilm LAS4000 FluorImager system. The blots were stripped using Restore Western Blot Stripping Buffer (ThermoScientific) for $15 \mathrm{~min}$ at RT, washed in TBST, and reprobed with a mouse antibody against GAPDH (1:5000, Millipore) as a loading control. The relative levels of immunoreactivity were quantified using Fujifilm Multi Gauge software.

2.9. Immunocytochemical Analysis. We used commercially available specific anti-NOP antibodies. Cells were fixed for 20 minutes in $4 \%$ paraformaldehyde in a $0.1 \mathrm{M}$ phosphate buffer ( $\mathrm{pH}$ 7.4) and incubated with primary antibodies (rabbit anti-ORL-1, 1:500, ProteinTech) for 2 days at $4^{\circ} \mathrm{C}$. After three washes in phosphate buffered saline (PBS), immunofluorescence was revealed by incubation for $2 \mathrm{~h}$ in the fluorochromeconjugated secondary antibody, Alexa Fluor555 donkey, antirabbit diluted 1:500 in 5\% NDS. Sections were then washed with $\mathrm{PB}$ and coverslipped with an Aquatex mounting medium (Merck, Darmstadt, Germany). Sections without primary antibodies were used as negative controls.

2.10. Functional $\left.{ }^{35} S\right] G T P \gamma S$ Binding Assay. Ipsilateral dorsal rat spinal cords (L4-L6) were collected 7 days after injury, $6 \mathrm{~h}$ after the last morning minocycline treatment and were prepared for the assay as previously described [44] with modifications. The membrane fractions of rat spinal cords were diluted in TEM buffer (50 mM Tris-HCl, $1 \mathrm{mM}$ EGTA, and $\left.5 \mathrm{mM} \mathrm{MgCl}_{2} ; \mathrm{pH} 7.4\right)$ to achieve the appropriate protein content for the assays ( $10 \mu \mathrm{g}$ of protein/sample).

The $\left[{ }^{35} \mathrm{~S}\right] \mathrm{GTP} \gamma \mathrm{S}$ assays were prepared according to Sim et al. [45] and Traynor and Nahorski [46] with slight modifications. The membrane fractions were incubated at $30^{\circ} \mathrm{C}$ for $60 \mathrm{~min}$ in Tris-EGTA buffer (composed of $50 \mathrm{mM}$ Tris$\mathrm{HCl}, 1 \mathrm{mM}$ EGTA, $3 \mathrm{mM} \mathrm{MgCl}_{2}$, and $100 \mathrm{mM} \mathrm{NaCl} ; \mathrm{pH}$ 7.4). The buffer also contained $20 \mathrm{MBq} / 0.05 \mathrm{~cm}^{3}\left[{ }^{35} \mathrm{~S}\right] \mathrm{GTP} \gamma \mathrm{S}$ $(0.05 \mathrm{nM})$ and increasing concentrations $\left(10^{-10}-10^{-5} \mathrm{M}\right)$ of 
N/OFQ 1-17 in the presence of excess GDP $(30 \mu \mathrm{M})$ in a final volume of $1 \mathrm{~mL}$. Total binding $(\mathrm{T})$ was measured in the absence of N/OFQ 1-17, while nonspecific binding (NS) was determined in the presence of $10 \mu \mathrm{M}$ unlabeled GTP $\gamma \mathrm{S}$ and subtracted from the total binding. The difference ( $\mathrm{T}$ NS) represents basal activity. Bound and free $\left[{ }^{35} \mathrm{~S}\right] \mathrm{GTP} \gamma \mathrm{S}$ were separated by vacuum filtration through Whatman GF/B filters with Brandel M24R cell harvester. Filters were washed

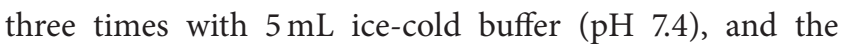
radioactivity of the filters was detected in UltimaGold MV aqueous scintillation cocktail with Packard Tricarb 2300TR liquid scintillation counter. $\left[{ }^{35} \mathrm{~S}\right] \mathrm{GTP} \gamma \mathrm{S}$ binding experiments were performed in triplicates and repeated at least three times.

2.11. Data Analysis. The behavioral data are presented as the mean \pm SEM of $8-16$ rats per group. The results of the experiments were statistically evaluated using one-way analysis of variance (ANOVA). All of the differences between the treatment groups were further analyzed with Bonferroni's post hoc tests. Significant differences in comparisons with vehicle-treated CCI-exposed rats are indicated by ${ }^{*} P(<0.05)$, ${ }^{* *} P(<0.01)$, and ${ }^{* * *} P(<0.001)$. Significant differences between vehicle-treated CCI-exposed rats that had received a single dose of N/OFQ and minocycline-treated CCI-exposed rats that had received a single dose of N/OFQ are indicated by ${ }^{\#} P(<0.05)$ and ${ }^{\# \#} P(<0.001)$.

The qRT-PCR analyses from the tissue were performed in three groups: naïve, vehicle-treated CCI-exposed, and minocycline-treated CCI-exposed rats. The results from 68 animals are presented as fold changes compared with the naive rats in the ipsilateral dorsal lumbar spinal cord. The results from 4 cell cultures are presented as fold changes compared with vehicle-treated cells. The qRT-PCR data are presented as the mean \pm SEM and represent the normalized averages that were derived from the threshold qRT-PCR cycles from four to eight samples for each group. Intergroup differences were analyzed using ANOVAs followed by Bonferroni's multiple comparison tests. In the cell cultures analysis, the intergroup differences were analyzed by $t$ test; significant differences resulting from comparisons with nonstimulated cells are indicated by ${ }^{*} P(<0.05)$.

The protein analyses were performed using Western blots. The analyses from the tissue were performed in three groups: naïve, vehicle-treated CCI-exposed, and minocycline-treated CCI-exposed rats. The results are presented as fold changes compared to the naïve rats in the ipsilateral dorsal lumbar spinal cord. The results from cell cultures are presented as fold changes compared with vehicle-treated cells. The data are presented as the mean \pm SEM and represent the normalized averages derived from analyses of four to five samples for each group (for tissue analysis) and four cell cultures performed with the Multi Gauge analysis program. Intergroup differences were analyzed using ANOVA followed by Bonferroni's multiple comparison tests. ${ }^{* *} P(<0.01)$ indicates significant differences compared to naïve rats. ${ }^{\#} P(<0.05)$ indicates significant differences compared to the CCI-treated group. In cell cultures analysis intergroup differences were analyzed with $t$-test.

In the $\left[{ }^{35} \mathrm{~S}\right] \mathrm{GTP} \gamma \mathrm{S}$ binding assays, the specifically bound $\left[{ }^{35} \mathrm{~S}\right] \mathrm{GTP} \gamma \mathrm{S}$ were presented as percentages as the function of the applied concentrations of N/OFQ 1-17 in logarithmic scale. Basal activity was settled as $100 \%$; experimental data are presented as the mean \pm S.E.M. The data were fitted with GraphPad Prism 5.0 (GraphPad Prism Software Inc., San Diego, CA) curve fitting program to determine the maximal stimulation or efficacy $\left(E_{\max }\right)$ of the receptor mediated Gprotein and the potency $\left(\mathrm{EC}_{50}\right)$ of the stimulator ligand. Statistical analysis was performed using one-way ANOVA with Bonferroni's multiple comparison post hoc test to determine the significance level. Significance was accepted at the ${ }^{*} P(<$ 0.05) level.

\section{Results}

3.1. Repeated Minocycline Administration Diminished the Development of Neuropathic Pain and Enhanced the Effectiveness of Nociceptin/Orphanin FQ. In the behavioral tests, all vehicle-treated CCI-exposed rats exhibited neuropathic pain symptoms. Seven days after injury, rats exhibited strong allodynia as measured by the von Frey test $(11.7 \mathrm{~g} \pm 0.6$ compared with $25.8 \mathrm{~g} \pm 0.2$ for naïve rats) (Figure 1(a)) and potent hyperalgesia as measured by the cold plate test $(7.6 \mathrm{~s} \pm$ 0.9 compared with $29.7 \mathrm{~s} \pm 0.3$ for naïve rats) (Figure $1(\mathrm{~b})$ ). Minocycline (30 mg/kg; i.p.) administered repeatedly was effective in reducing mechanical allodynia as measured by the von Frey test (vehicle-treated $11.7 \mathrm{~g} \pm 0.6$ versus minocyclinetreated $18.0 \mathrm{~g} \pm 0.6$ ) (Figure $1(\mathrm{a})$ ) and also in reducing cold hyperalgesia as measured by the cold plate test (vehicletreated $7.6 \mathrm{~s} \pm 0.9$ versus $12.1 \mathrm{~s} \pm 0.9$ minocycline-treated) (Figure 1(b)).

N/OFQ (2.5 and $5 \mu$ g; i.t.) was injected at day 7 at one hour after the last morning dose of minocycline $(30 \mathrm{mg} / \mathrm{kg}$; i.p.) or vehicle. The effect of N/OFQ $(2.5 \mu \mathrm{g} ; 5 \mu \mathrm{g} / \mu \mathrm{L}$; i.t.) in minocycline-treated rats as compared with vehicle-treated ones was significantly increased in the von Frey test 20 and 40 minutes after injection (Figure 1(a)). The antihyperalgesic effect of the lower dose of N/OFQ $(2.5 \mu \mathrm{g} / \mu \mathrm{L}$; i.t. $)$ in minocycline-treated rats compared with vehicle-treated rats was significantly upregulated only after 50 minutes, while at a higher dose $(5 \mu \mathrm{g} / \mu \mathrm{L}$; i.t.) the antihyperalgesic effect was potentiated at both times (Figure 1(b)).

3.2. Repeated Minocycline Administration Influenced the Nociceptin/Orphanin FQ System Parallel to Microglia Regulation in the Spinal Cord Level under Neuropathic Pain. Seven days after CCI in the ipsilateral lumbar dorsal spinal cord an increase of $60 \%$ of NOP protein was observed compared with naive animals (Figure 2(b)). Repeated administration of minocycline reduced the upregulation of NOP protein level (by 24\%) in comparison with naive rats (Figure 2(b)). No changes in NOP mRNA were seen in the vehicleor the minocycline-treated rats compared with naive animals (Figure 2(a)). Parallel to NOP protein regulation, we observed the upregulation of protein by $185 \%$ for IBA-1 


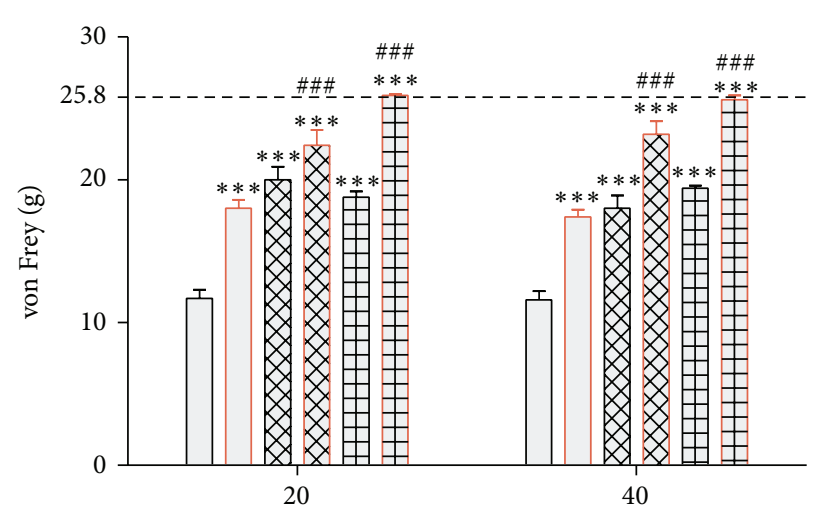

(a)

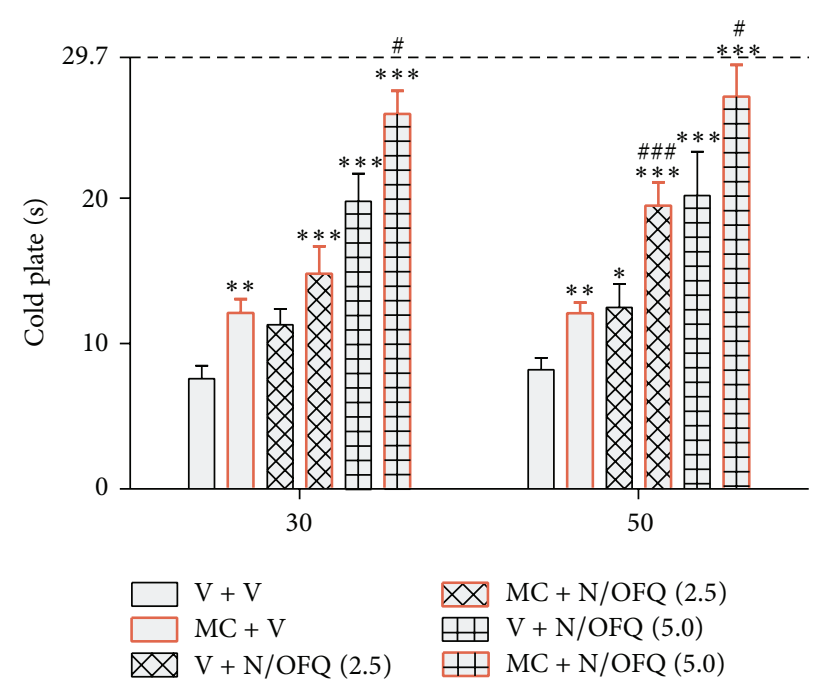

(b)

FIGURE 1: Repeated minocycline administration diminished the development of neuropathic pain and enhanced the effectiveness of N/OFQ. The response to N/OFQ was measured 20 and 40 minutes after administration by the von Frey test (a) and 30 and 50 minutes after administration by the cold plate test (b). Minocycline (MC; $30 \mathrm{mg} / \mathrm{kg}$; i.p.) was administered intraperitoneally preemptively $16 \mathrm{~h}$ and $1 \mathrm{~h}$ before $\mathrm{CCI}$ and then repeatedly twice daily for 7 days. Vehicle-treated and minocycline-treated rats received intrathecal N/OFQ $(2.5 ; 5 \mu \mathrm{g} / 5 \mu \mathrm{L})$ one hour after the last morning administration on day 7 after CCI. The data are presented as the mean response \pm SEM. (8-16 rats per group). The results of the experiments were statistically evaluated using one-way analyses of variance (ANOVA). The differences between the treatment groups throughout the study were further analyzed with Bonferroni's post hoc tests. ${ }^{*} P<0.05,{ }^{* *} P<0.01$, and ${ }^{* * *} P<0.001$ indicate significant differences compared with vehicle-treated CCI-exposed rats; ${ }^{\#} P<0.05$ and ${ }^{\# \# \# ~} P<0.001$ indicate significant differences between vehicle-treated CCI-exposed rats that received a single dose of N/OFQ and minocycline-treated CCI-exposed rats that received a single dose of N/OFQ. The dotted line is a value for naïve animals (von Frey test $25.8 \mathrm{~g}$; cold plate test $29.7 \mathrm{~s}$ ).

(a microglial marker) in the ipsilateral lumbar dorsal spinal cord in the vehicle-treated rats (Figure 2(c)). Repeated administration of minocycline diminished the level of microglial activation marker to $57 \%$ in comparison with naive rats (Figure 2(c)).

3.3. Repeated Minocycline Administration Influenced Nociceptin/Orphanin FQ Peptide Receptor Signaling under Neuropathic Pain. In the $\left[{ }^{35} \mathrm{~S}\right] \mathrm{GTP} \gamma \mathrm{S}$ binding assay, during N/OFQ stimulation in the ipsilateral lumbar dorsal rat spinal cord CCI-exposed rats remained unaffected compared to the naive group. However, repeated minocycline treatment markedly increased the specific binding of the nucleotide analogue during NOP-mediated G-protein activation (Figure 3(b)). This resulted in a significant increase in the maximal activation (or efficacy, $E_{\max }$ ) of NOP-mediated G-protein compared with the vehicle-treated CCI-exposed group (Figure 3(a)). The potency $\left(\mathrm{pEC}_{50}\right)$ of the ligand remained unaltered (data not shown; the curves did not shift to either side to a significant degree) compared to naive either to vehicle treated CCIexposed animals (Figure 3(b)).

\subsection{Minocycline Influenced the Nociceptin/Orphanin FQ Pep-} tide Receptor mRNA but Not Protein Levels in Rat Primary Microglial Cell Cultures. Rat primary microglial cell cultures were treated with minocycline $(10 \mu \mathrm{M})$ for $6 \mathrm{~h}$ and $24 \mathrm{~h}$ for mRNA and protein analysis, respectively. The qRT-PCR analysis shows that minocycline downregulates NOP mRNA in comparison with vehicle-treated cells (Figure 4(a)). Using Western blot analysis we have shown that minocycline did not have influence on the protein level of NOP after $24 \mathrm{~h}$ treatment in primary microglial cell cultures in comparison with vehicle-treated cells (Figure 4(b)). The presence of NOP in microglial cells was confirmed by immunocytochemistry (Figure 4(c)).

\section{Discussion}

Numerous pain studies are focused on the N/OFQ system because it is known that at the spinal cord level N/OFQ shows antinociceptive action through NOP, present in sensory neurons. NOP is considered as a novel potential target in the pain therapy. However, the role played by microglia in the functioning of this system has not been studiedthus far. In the present study, we have shown for the first time the important influence of microglial activation on the effectiveness of the N/OFQ system. We demonstrated that repeated administration of minocycline potentiated the analgesic effects of N/OFQ in neuropathic rats and the effect seems to be additive. Chronic minocycline administration reduced the elevated spinal level of NOP protein of CCIexposed rats, and it significantly increased NOP signaling possibly through the upregulation of NOP coupled $\mathrm{G}_{\mathrm{i}}$ protein activation. Interestingly, in our in vitro studies we had shown that minocycline downregulates mRNA level for NOP in primary microglial cell cultures. 


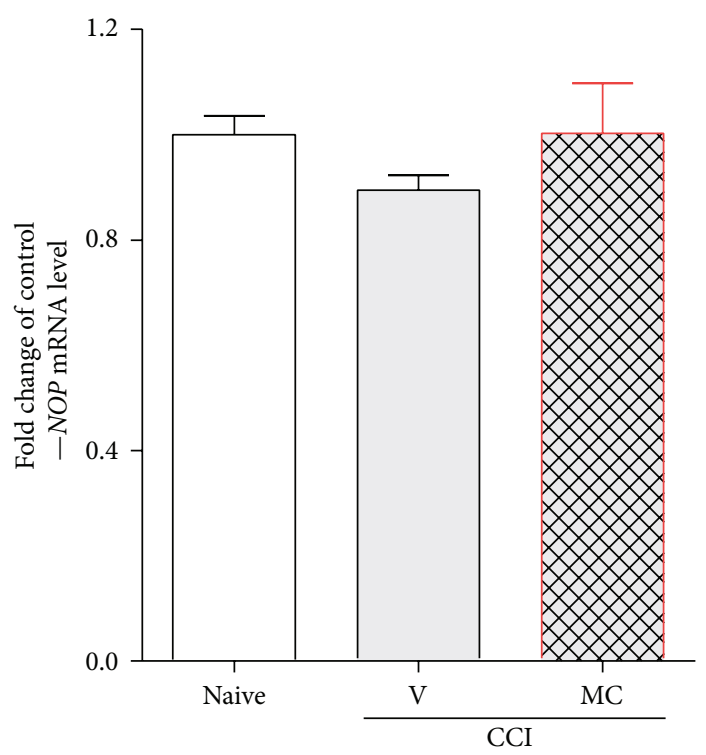

(a)

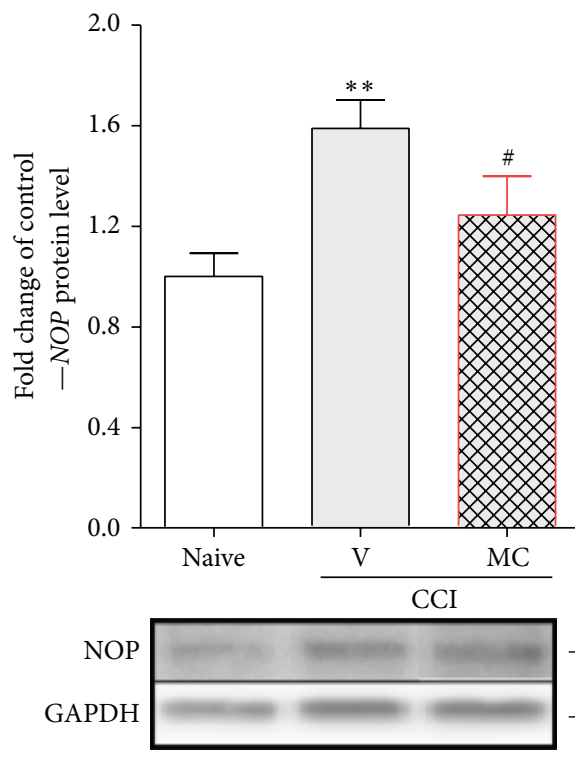

(b)

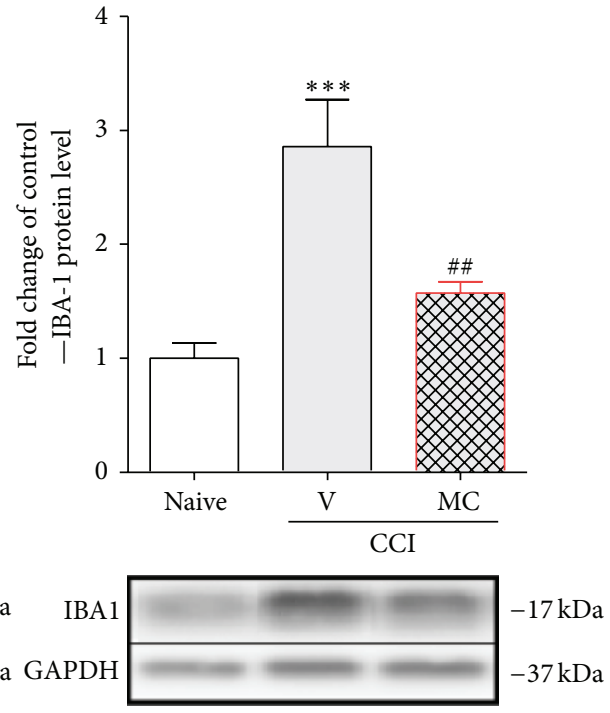

(c)

Figure 2: Repeated minocycline administration influenced the N/OFQ system parallel to microglia regulation in the spinal cord level under the neuropathic pain. Seven days after CCI in the ipsilateral dorsal spinal cord, minocycline-treatment diminished the level of NOP (b) and IBA-1 (c) proteins levels that were upregulated by nerve injury. The NOP mRNA level was unchanged by nerve injury and minocycline treatment (a). The qRT-PCR and Western blot data are presented as the mean \pm SEM and represent the normalized averages derived from analyses of 4-8 samples for each group. Intergroup differences were analyzed using ANOVA followed by Bonferroni's multiple comparison test. ${ }^{* *} P<0.01$ and ${ }^{* * *} P<0.001$ indicate significant differences compared with naïve rats. ${ }^{\#} P<0.05$ and ${ }^{\# \#} P<0.01$ indicate significant differences comp ared with the CCI-treated group. V: vehicle, MC: minocycline.

The N/OFQ analgesic activity is mediated selectively by NOP [3, 47, 48], which has been shown to act through the same intracellular pathway as classical opioid receptors $[3,7]$. In healthy animals, N/OFQ administered i.t. has been generally found to produce antinociceptive responses that are similar to classical opioid receptor agonists without inducing signs of sedation or motor impairment [3, 10-14, 49,50 ] which is why this system seems to be a promising target for chronic pain treatment. N/OFQ administered i.t. in neuropathic pain strongly alleviates both allodynia and hyperalgesia $[4,5,48,51,52]$, and these results are in agreement with our behavioral results shown in the present paper. Additionally, electrophysiological studies have confirmed that the antinociceptive potency of spinally administered $\mathrm{N} / \mathrm{OFQ}$ is maintained or even enhanced after nerve injury [14]. This is in contrast with classic opioid receptor agonists, 

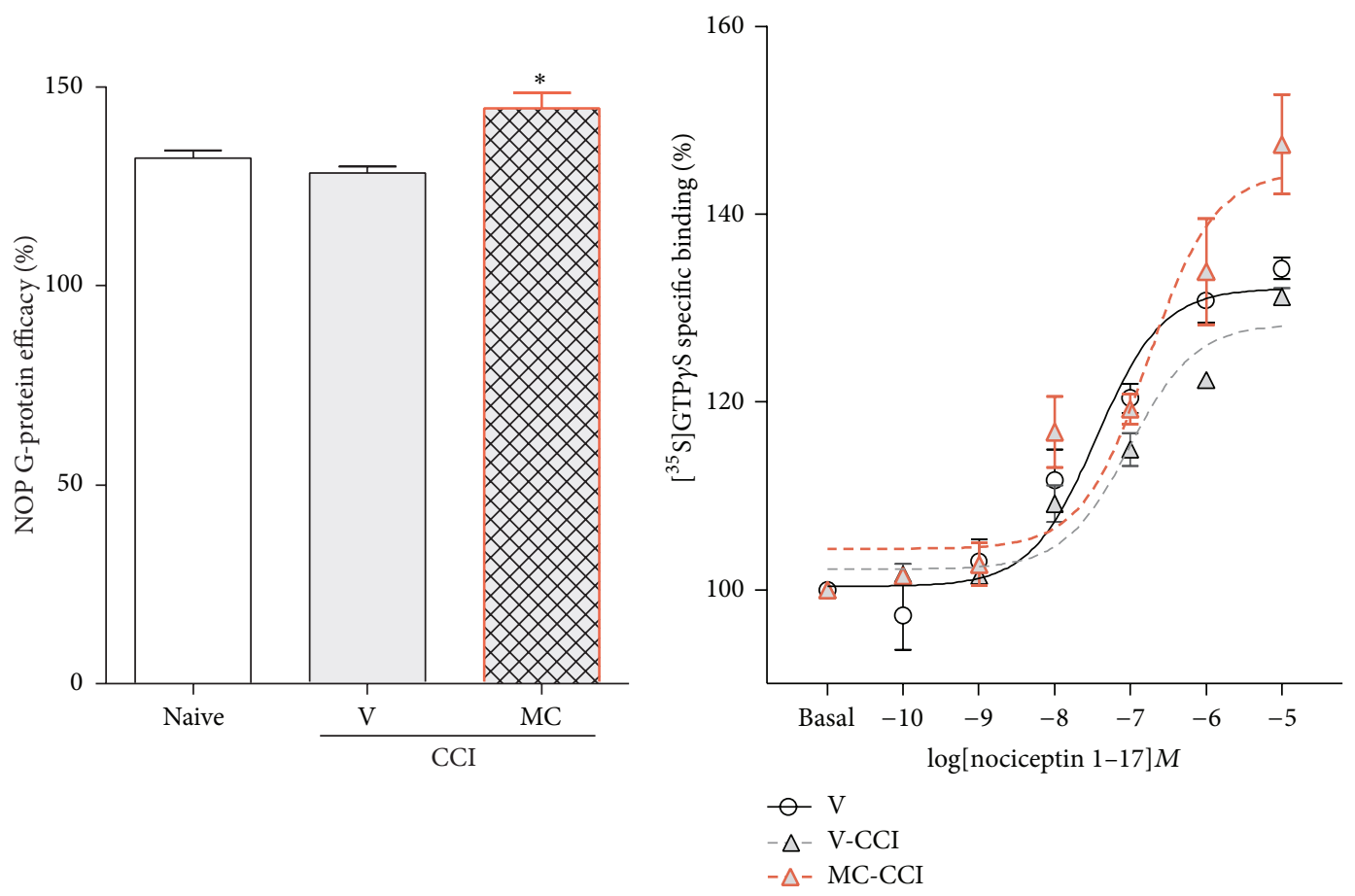

(a)

(b)

FIGURE 3: Repeated minocycline administration influenced NOP signaling. Chronic i.p. ( $30 \mathrm{mg} / \mathrm{kg})$ minocycline treatment significantly increased the specific binding of the nucleotide analogue on NOP G-protein compared to vehicle-treated CCI-exposed rats. (a) The figure represents the calculated efficacy (or $E_{\max }$ ) of the NOP-mediated G-protein during ligand stimulation. (b) The figure represents the specifically bound $\left[{ }^{35} \mathrm{~S}\right] \mathrm{GTP} \gamma \mathrm{S}$ as a percentage in the presence of increasing concentrations $\left(10^{10}-10^{-5} \mathrm{M}\right)$ of N/OFQ 1-17. Basal activity was settled as $100 \%$. Points and columns represent mean \pm SEM. for at least three experiments performed in triplicates. Intergroup differences were analyzed using ANOVA followed by Bonferroni's multiple comparison test. ${ }^{*} P<0.05$ indicates significant differences compared with naïve rats. V: vehicle, MC: minocycline.

such as morphine, which are less effective in neuropathic than in acute pain conditions, making the N/OFQ system a much more effective target in neuropathic pain treatment [53].

$\mathrm{N} / \mathrm{OFQ}$ and its receptor are localized in nervous system regions that are associated with nociception [22-24, 54]. Using immunoreactivity-based approaches, NOP protein has been detected in the gray matter of the spinal cord, particularly in the superficial layer II of the lumbar dorsal horn $[9,27]$. Therefore, for our biochemical analysis we used dorsal part of the lumbar spinal cord L4-L6. Luo et al. [55] have shown that in the dorsal horn N/OFQ suppresses excitatory, but not inhibitory (glycinergic or GABAergic), synaptic transmission to substantia gelatinosa neurons. It has been clearly documented that the induction of chronic pain states, especially neuropathy, is associated with a regulation of the N/OFQ system $[51,56,57]$.

It is suggested that the development of neuropathic pain conditions is caused by abnormal glial cell activation, especially microglia [58-62]. However, there is a lack of information on whether NOP can be expressed and regulated on microglial cells in the spinal cord during neuropathy. It is well known that microglial cells in the spinal cord become activated in response to injury [17, 61, 63-65] and may modulate pain by producing pronociceptive substances, such as cytokines (IL-1beta, TNFalpha, IL-6, fractalkine, MIPlalpha, MIP-1beta, and MCP-1), cytokine receptors (TNFRI, TNFRII, IL-1RI, and CX3CR1), cytotoxic compounds (iNOS, NO, ROS, and ATP), prostaglandins, and excitatory amino acids [62, 66-71]. In our previous studies, we have shown that minocycline diminished the development of neuropathic pain in CCI-exposed rats [41, 64]. In our experiments, we used minocycline, which besides some influence on neurons $[72,73]$, is considered as an inhibitor of the microglial activation [29-32], viability, and migration [33, 34] during neuropathic pain. In our previous experiments, we observed that minocycline can enhance the antiallodynic and antihyperalgesic effects of morphine, DAMGO, and $\mathrm{U} 50,488 \mathrm{H}$ but not DPDPE, deltorphin II, or SNC80 [74]. In the present study, we demonstrated for the first time that in CCI-exposed rats the antiallodynic and antihyperalgesic effects of N/OFQ were significantly potentiated by minocycline, similar to opioid agonists.

Our biochemical study shows strong ipsilateral upregulation of protein for NOP parallel to microglial cell activation, while fewer changes are observed in minocycline-treated rats. In our earlier experiments using in situ hybridization, we have shown that the upregulation of NOP mRNA occurred only in the ventral but not the dorsal horn of ipsilateral lumbar part of 


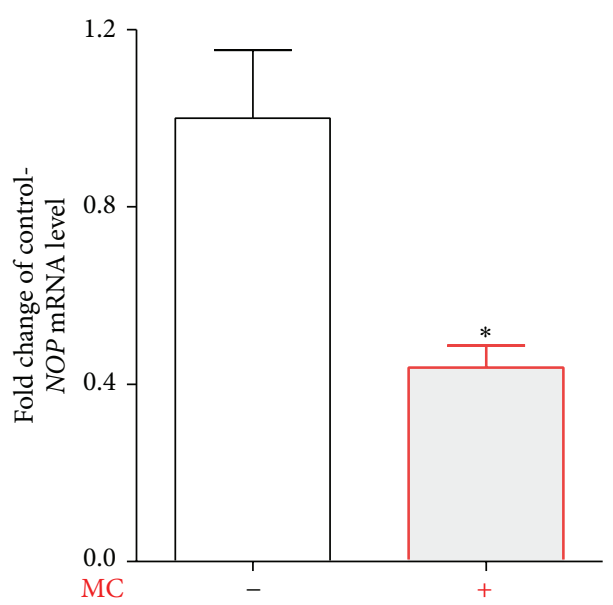

(a)

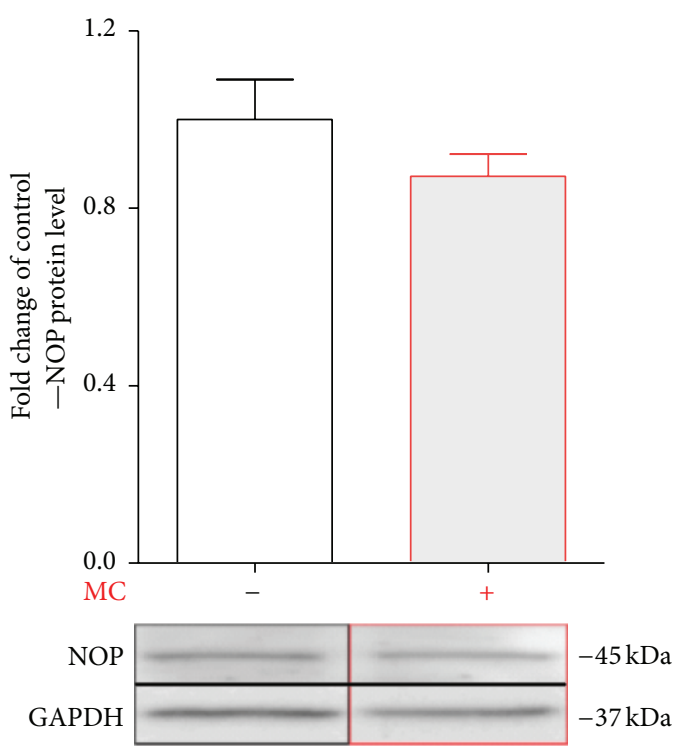

(b)

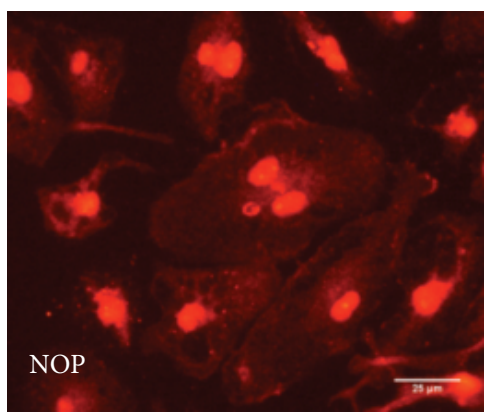

(c)

FIgURE 4: Minocycline diminished the mRNA but not protein NOP level in primary microglial cells. Primary microglial cell cultures were treated with minocycline [MC; $10 \mu \mathrm{M}$ ] for $6 \mathrm{~h}$ for mRNA analysis (a) and $24 \mathrm{~h}$ for protein analysis (b). The qRT-PCR analysis shows that minocycline $[10 \mu \mathrm{M}]$ downregulates NOP mRNA in primary microglial cell cultures (a). The Western blot analysis shows that minocycline did not change the protein level of NOP in primary microglia cultures (b). The qRT-PCR and Western blot data are presented as the mean \pm SEM and represent the normalized averages derived from the analyses of four experiments. The intergroup differences were analyzed with a $t$-test; significant differences resulting from comparison with nonstimulated cells are indicated by ${ }^{*} P<0.05$. The presence of NOP on microglial cells was confirmed by immunocytochemistry (c). The scale bar for all microphotographs is $25 \mu \mathrm{m}$.

the spinal cord, suggesting it is increased in motoneurons [6]. Similarly, Briscini et al. [51] showed the upregulation of NOP mRNA in the whole (dorsal and ventral) ipsilateral lumbar enlargement. In our present study, no changes in NOP mRNA level were observed in the spinal dorsal part at L4-L6 in either vehicle- or minocycline-treated rats compared to naive animals.

Our results suggest that the alterations in the spinal N/OFQ signaling by minocycline treatment change the effectiveness of coupled $G_{i}$ proteins which in turn compensates for neuropathic pain. G-protein activation was monitored in functional $\left[{ }^{35} \mathrm{~S}\right] \mathrm{GTP} \gamma \mathrm{S}$ binding assays using N/OFQ 1-17 to activate the receptor. The unaffected potency of N/OFQ shows that the binding site of the receptor is unaltered in CCI-exposed rats after vehicle or minocycline injection. We have shown that minocycline caused an increase in N/OFQstimulated NOP signaling and influenced the N/OFQ system functionality during neuropathic pain.

The downregulation of the NOP by minocycline is in parallel with a reduced level of IBA-1 protein, which suggests that microglia play an important role in this phenomenon. In 2010, Mika et al. [17] demonstrated by using immunohistochemistry that repeated minocycline treatment reversed the injury-induced activation of microglia/macrophages in the dorsal lumbar spinal cord. Our present data suggest that the changes in the NOP affect not only neurons but also results from glial cells activation, which is in agreement with previous reports $[20,21,72]$. Using primary microglial cell cultures, we have shown for the first time that minocycline downregulates the level of NOP mRNA in microglial cells. 


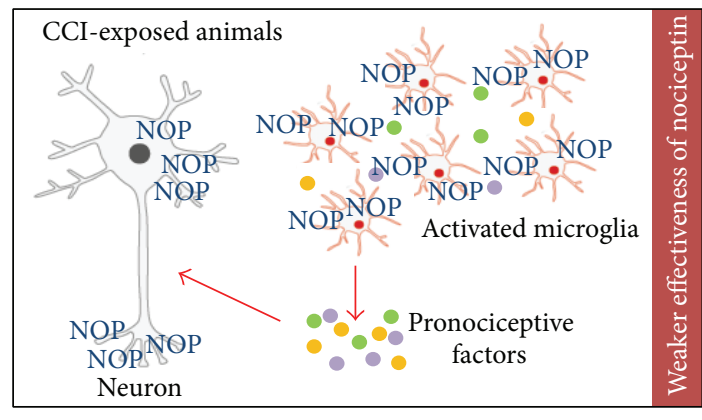

(a)

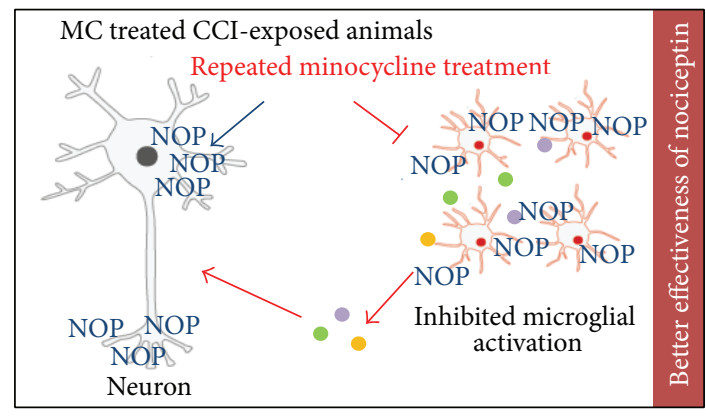

(b)

Scheme 1: Based on our results, we hypothesize the possible influence of minocycline on the N/OFQ system during neuropathic pain. Activated spinal microglia are key factors in the development of neuropathic pain by producing pronociceptive substances [65] and they play a role in the efficacy of analgesics (a). Minocycline (MC) potentiated the effects of N/OFQ through the downregulation of microglial activation, which leads to decrease of the microglial pool of NOP at the spinal cord level. This action of minocycline leads to increasing the analgesic effects of N/OFQ through neuronal receptors (b).

Our results may suggest that observed changes in NOP protein level after minocycline administration in a rat model of neuropathic pain can occur as result of the inhibition of microglial activation.

\section{Summary}

Minocycline potentiates the effects of N/OFQ through the downregulation of microglial activation and also by decreasing the microglial pool of NOP. Thus, it increases the analgesic action of N/OFQ through neuronal receptors, and it also potentiates the receptor-ligand signaling through the upregulation of G-protein activation. The results of the present study provide evidence that minocycline not only diminishes neuropathic pain-related behavior, but also enhances the effectiveness of N/OFQ by modulation of NOP expression and activity (Scheme 1). Our findings suggest that activated spinal microglial cells, which are the key factors in the development of neuropathic pain, play an important role in the function of the N/OFQ system. Therefore, specific microglial modulators, such as minocycline, combined with N/OFQ may be an interesting target to develop new therapy that would be effective against neuropathic pain.

\section{Conflict of Interests}

The authors declare that there is no conflict of interests regarding the publication of this paper.

\section{Acknowledgments}

This work was supported by Grant OPUS NCN 2011/03/B/ NZ4/00042, Grant PRELUDIUM NCN 2012/07/N/NZ3/ 00379, and statutory funds. Katarzyna Popiolek-Barczyk and Agnieszka M. Jurga are recipients of a scholarship from the KNOW sponsored by the Ministry of Science and Higher Education, Poland.

\section{References}

[1] S. Arner and B. A. Meyerson, "Lack of analgesic effect of opioids on neuropathic and idiopathic forms of pain," Pain, vol. 33, no. 1, pp. 11-23, 1988.

[2] M. H. Ossipov, Y. Lopez, M. L. Nichols, D. Bian, and F. Porreca, "The loss of antinociceptive efficacy of spinal morphine in rats with nerve ligation injury is prevented by reducing spinal afferent drive," Neuroscience Letters, vol. 199, no. 2, pp. 87-90, 1995.

[3] R. K. Reinscheid, H. Nothacker, A. Bourson et al., "Orphanin FQ: a neuropeptide that activates an opioidlike G proteincoupled receptor," Science, vol. 270, no. 5237, pp. 792-794, 1995.

[4] C. Courteix, M. Coudoré-Civiale, A. Privat, T. Pélissier, A. Eschalier, and J. Fialip, "Evidence for an exclusive antinociceptive effect of nociceptin/orphanin FQ, an endogenous ligand for the ORL1 receptor, in two animal models of neuropathic pain," Pain, vol. 110, no. 1-2, pp. 236-245, 2004.

[5] T. Yamamoto, N. Nozaki-Taguchi, and S. Kimura, "Effects of intrathecally administered nociceptin, an opioid receptor-likel (ORL1) receptor agonist, on the thermal hyperalgesia induced by unilateral constriction injury to the sciatic nerve in the rat," Neuroscience Letters, vol. 224, no. 2, pp. 107-110, 1997.

[6] J. Mika, I. Obara, and B. Przewlocka, "The role of nociceptin and dynorphin in chronic pain: Implications of neuro-glial interaction," Neuropeptides, vol. 45, no. 4, pp. 247-261, 2011.

[7] J. Meunier, C. Mollereau, L. Toll et al., "Isolation and structure of the endogenous agonist of opioid receptor-like ORL1 receptor," Nature, vol. 377, no. 6549, pp. 532-535, 1995.

[8] C. Suaudeau, S. Florin, J.-C. Meunier, and J. Costentin, "Nociceptin- induced apparent hyperalgesia in mice as a result of the prevention of opioid autoanalgesicmechanisms triggered by the stress of an intracerebroventricular injection," Fundamental and Clinical Pharmacology, vol. 12, no. 4, pp. 420-425, 1998.

[9] G. Calo, R. Guerrini, A. Rizzi, S. Salvadori, and D. Regoli, "Pharmacology of nociceptin and its receptor: a novel therapeutic target," British Journal of Pharmacology, vol. 129, no. 7, pp. 1261$1283,2000$.

[10] K. H. Jhamandas, M. Sutak, and G. Henderson, "Antinociceptive and morphine modulatory actions of spinal orphanin FQ," Canadian Journal of Physiology and Pharmacology, vol. 76, no. 3, pp. 314-324, 1998.

[11] J. Tian, W. Xu, W. Zhang et al., "Involvement of endogenous orphanin FQ in electroacupuncture-induced analgesia," NeuroReport, vol. 8, no. 2, pp. 497-500, 1997. 
[12] Y. Wang, C. Zhu, X. Cao, and G. Wu, "Supraspinal hyperalgesia and spinal analgesia by [Phel $\psi(\mathrm{CH} 2-\mathrm{NH}) \mathrm{Gly} 2]$ nociceptin-(113)-NH2 in rat," European Journal of Pharmacology, vol. 376, no. 3, pp. R1-R3, 1999.

[13] X. Xu, J. Hao, and Z. Wiesenfeld-Hallin, "Nociceptin or antinociceptin: potent spinal antinociceptive effect of orphanin FQ/nociceptin in the rat," NeuroReport, vol. 7, no. 13, pp. 20922094, 1996.

[14] X. Xu, S. Grass, J. Hao, I. Shi Xu, and Z. Wiesenfeld-Hallin, "Nociceptin/orphanin FQ in spinal nociceptive mechanisms under normal and pathological conditions," Peptides, vol. 21, no. 7, pp. 1031-1036, 2000.

[15] J. Mika, Y. Li, E. Weihe, and M. K. Schafer, "Relationship of pronociceptin/orphanin FQ and the nociceptin receptor ORL1 with substance $P$ and calcitonin gene-related peptide expression in dorsal root ganglion of the rat," Neuroscience Letters, vol. 348, no. 3, pp. 190-194, 2003.

[16] J. Mika, M. K. H. Schäfer, I. Obara, E. Weihe, and B. Przewlocka, "Morphine and endomorphin-1 differently influence pronociceptin/orphanin FQ system in neuropathic rats," Pharmacology Biochemistry and Behavior, vol. 78, no. 1, pp. 171-178, 2004.

[17] J. Mika, E. Rojewska, W. Makuch, and B. Przewlocka, "Minocycline reduces the injury-induced expression of prodynorphin and pronociceptin in the dorsal root ganglion in a rat model of neuropathic pain," Neuroscience, vol. 165, no. 4, pp. 1420-1428, 2010.

[18] A. C. Eschenroeder, A. A. Vestal-Laborde, E. S. Sanchez, S. E. Robinson, and C. Sato-Bigbee, "Oligodendrocyte responses to buprenorphine uncover novel and opposing roles of $\mu$-opioidand nociceptin/orphanin FQ receptors in cell development: implications for drug addiction treatment during pregnancy," GLIA, vol. 60, no. 1, pp. 125-136, 2012.

[19] K. Sakoori and N. P. Murphy, "Reduced degeneration of dopaminergic terminals and accentuated astrocyte activation by high dose methamphetamine administration in nociceptin receptor knock out mice," Neuroscience Letters, vol. 469, no. 3, pp. 309-313, 2010.

[20] X. Fu, Z.-H. Zhu, Y.-Q. Wang, and G.-C. Wu, "Regulation of proinflammatory cytokines gene expression by nociceptin/orphanin FQ in the spinal cord and the cultured astrocytes," Neuroscience, vol. 144, no. 1, pp. 275-285, 2007.

[21] H. Zhao, G. Wu, and X. Cao, "Immunomodulatory activity of orphanin FQ/nociceptin on traumatic rats," Acta Pharmacologica Sinica, vol. 23, no. 4, pp. 343-348, 2002.

[22] B. Anton, J. Fein, T. To, X. Li, L. Silberstein, and C. J. Evans, "Immunohistochemical localization of ORL-1 in the central nervous system of the rat," The Journal of Comparative Neurology, vol. 368, no. 2, pp. 229-251, 1996.

[23] J. R. Bunzow, C. Saez, M. Mortrud et al., "Molecular cloning and tissue distribution of a putative member of the rat opioid receptor gene family that is not a mu, delta or kappa opioid receptor type," FEBS Letters, vol. 347, no. 2-3, pp. 284-288, 1994.

[24] M. J. Wick, S. R. Minnerath, X. Lin, R. Elde, P. Law, and H. H. Loh, "Isolation of a novel cDNA encoding a putative membrane receptor with high homology to the cloned $\mu, \delta$, and $\kappa$ opioid receptors," Molecular Brain Research, vol. 27, no. 1, pp. 37-44, 1994.

[25] K. Fukuda, "cDNA cloning and regional distribution of a novel member of the opioid receptor family," FEBS Letters, vol. 343, no. 1, pp. 42-46, 1994.
[26] J. Meunier, L. Mouledous, and C. M. Topham, “The nociceptin (ORL1) receptor: molecular cloning and functional architecture," Peptides, vol. 21, no. 7, pp. 893-900, 2000.

[27] C. Mollereau and L. Mouledous, "Tissue distribution of the opioid receptor-like (ORL1) receptor," Peptides, vol. 21, no. 7, pp. 907-917, 2000.

[28] H. Nothacker, R. K. Reinscheid, A. Mansour et al., "Primary structure and tissue distribution of the orphanin FQ precursor," Proceedings of the National Academy of Sciences of the United States of America, vol. 93, no. 16, pp. 8677-8682, 1996.

[29] J. Mika, M. Zychowska, W. Makuch, E. Rojewska, and B. Przewlocka, "Neuronal and immunological basis of action of antidepressants in chronic pain-clinical and experimental studies," Pharmacological Reports, vol. 65, no. 6, pp. 1611-1121, 2013.

[30] F. Zhu, Y. Zheng, Y. Q. Ding et al., "Minocycline and risperidone prevent microglia activation and rescue behavioral deficits induced by neonatal intrahippocampal injection of lipopolysaccharide in rats," PLoS ONE, vol. 9, no. 4, Article ID e93966, 2014.

[31] F. Zhu, Y. Liu, J. Zhao, and Y. Zheng, "Minocycline alleviates behavioral deficits and inhibits microglial activation induced by intrahippocampal administration of Granulocyte-Macrophage Colony-Stimulating Factor in adult rats," Neuroscience, vol. 266, pp. 275-281, 2014.

[32] K. Liaury, T. Miyaoka, T. Tsumori et al., "Minocycline improves recognition memory and attenuates microglial activation in Gunn rat: a possible hyperbilirubinemia-induced animal model of schizophrenia," Progress in Neuro-Psychopharmacology and Biological Psychiatry, vol. 50, pp. 184-190, 2014.

[33] N. Nutile-McMenemy, A. Elfenbein, and J. A. DeLeo, "Minocycline decreases in vitro microglial motility, $\beta_{1}$ - integrin, and Kv1.3 channel expression," Journal of Neurochemistry, vol. 103, no. 5, pp. 2035-2046, 2007.

[34] V. W. Yong, F. Giuliani, M. Xue, A. Bar-Or, and L. M. Metz, "Experimental models of neuroprotection relevant to multiple sclerosis," Neurology, vol. 68, no. 22, supplement 3, pp. S32-S37, 2007.

[35] M. Zimmermann, "Ethical guidelines for investigations of experimental pain in conscious animals," Pain, vol. 16, no. 2, pp. 109-110, 1983.

[36] C. Kilkenny, W. Browne, I. C. Cuthill, M. Emerson, and D. G. Altman, "Animal research: reporting in vivo experiments: the ARRIVE guidelines," British Journal of Pharmacology, vol. 160, no. 7, pp. 1577-1579, 2010.

[37] G. J. Bennett and Y. K. Xie, "A peripheral mononeuropathy in rat that produces disorders of pain sensation like those seen in man," Pain, vol. 33, no. 1, pp. 87-107, 1988.

[38] M. Osikowicz, J. Mika, W. Makuch, and B. Przewlocka, "Glutamate receptor ligands attenuate allodynia and hyperalgesia and potentiate morphine effects in a mouse model of neuropathic pain," Pain, vol. 139, no. 1, pp. 117-126, 2008.

[39] T. L. Yaksh and T. A. Rudy, "Chronic catheterization of the spinal subarachnoid space," Physiology and Behavior, vol. 17, no. 6, pp. 1031-1036, 1976.

[40] W. Makuch, J. Mika, E. Rojewska, M. Zychowska, and B. Przewlocka, "Effects of selective and non-selective inhibitors of nitric oxide synthase on morphine- and endomorphin1-induced analgesia in acute and neuropathic pain in rats," Neuropharmacology, vol. 75, pp. 445-447, 2013.

[41] J. Mika, M. Osikowicz, W. Makuch, and B. Przewlocka, "Minocycline and pentoxifylline attenuate allodynia and hyperalgesia and potentiate the effects of morphine in rat and mouse 
models of neuropathic pain," European Journal of Pharmacology, vol. 560, no. 2-3, pp. 142-149, 2007.

[42] M. Zawadzka and B. Kaminska, "A novel mechanism of FK506mediated neuroprotection: downregulation of cytokine expression in glial cells," GLIA, vol. 49, no. 1, pp. 36-51, 2005.

[43] P. Chomczynski and N. Sacchi, "Single-step method of RNA isolation by acid guanidinium thiocyanate-phenol-chloroform extraction," Analytical Biochemistry, vol. 162, no. 1, pp. 156-159, 1987.

[44] S. Benyhe, J. Farkas, G. Tóth, and M. Wollemann, "Met5enkephalin-Arg6-Phe7, an endogenous neuropeptide, binds to multiple opioid and nonopioid sites in rat brain," Journal of Neuroscience Research, vol. 48, no. 3, pp. 249-258, 1997.

[45] L. J. Sim, D. E. Selley, and S. R. Childers, "In vitro autoradiography of receptor-activated $\mathrm{G}$ proteins in rat brain by agoniststimulated guanylyl 5/-[ $\gamma$-[35S]thio]-triphosphate binding," Proceedings of the National Academy of Sciences of the United States of America, vol. 92, no. 16, pp. 7242-7246, 1995.

[46] J. R. Traynor and S. R. Nahorski, "Modulation by $\mu$-opioid agonists of guanosine-5/-O-(3-[35S]thio)triphosphate binding to membranes from human neuroblastoma SH-SY5Y cells," Molecular Pharmacology, vol. 47, no. 4, pp. 848-854, 1995.

[47] F. A. Abdulla and P. A. Smith, "Axotomy reduces the effect of analgesic opioids yet increases the effect of nociceptin on dorsal root ganglion neurons," Journal of Neuroscience, vol. 18, no. 23, pp. 9685-9694, 1998.

[48] I. Obara, R. Przewlocki, and B. Przewlocka, "Spinal and local peripheral antiallodynic activity of Ro64-6198 in neuropathic pain in the rat," Pain, vol. 116, no. 1-2, pp. 17-25, 2005.

[49] X. Zhang, C. Zhu, S. Xu et al., "Effect of intrathecal or intracerebroventricular administration of OFQ on pain threshold and acpuncture analgesia in rats," Acta Physiologica Sinica, vol. 49, no. 5, pp. 575-580, 1997.

[50] C. Zhu, X. Zhang, S. Xu et al., "Antagonistic effect of orphanin FQ on opioid analgesia in rat," Acta Pharmacologica Sinica, vol. 19, no. 1, pp. 10-14, 1998.

[51] L. Briscini, L. Corradini, E. Ongini, and R. Bertorelli, "Upregulation of ORL-1 receptors in spinal tissue of allodynic rats after sciatic nerve injury," European Journal of Pharmacology, vol. 447, no. 1, pp. 59-65, 2002.

[52] T. Yamamoto, S. Ohtori, and T. Chiba, "Inhibitory effect of intrathecally administered nociceptin on the expression of Foslike immunoreactivity in the rat formalin test," Neuroscience Letters, vol. 284, no. 3, pp. 155-158, 2000.

[53] W. Schröder, D. G. Lambert, M. C. Ko, and T. Koch, "Functional plasticity of the N/OFQ-NOP receptor system determines analgesic properties of NOP receptor agonists," The British Journal of Pharmacology, vol. 171, no. 16, pp. 3777-3800, 2014.

[54] J. S. Mogil and G. W. Pasternak, "The molecular and behavioral pharmacology of the orphanin FQ/nociceptin peptide and receptor family," Pharmacological Reviews, vol. 53, no. 3, pp. 381415, 2001.

[55] C. Luo, E. Kumamoto, H. Furue, J. Chen, and M. Yoshimura, "Nociceptin inhibits excitatory but not inhibitory transmission to substantia gelatinosa neurones of adult rat spinal cord," Neuroscience, vol. 109, no. 2, pp. 349-358, 2002.

[56] A. Rosén, T. Lundeberg, B. Bytner, and I. Nylander, "Central changes in nociceptin dynorphin B and Met-enkephalin-ArgPhe in different models of nociception," Brain Research, vol. 857, no. 1-2, pp. 212-218, 2000.
[57] Y. Chen and C. Sommer, "Nociceptin and its receptor in rat dorsal root ganglion neurons in neuropathic and inflammatory pain models: Implications on pain processing," Journal of the Peripheral Nervous System, vol. 11, no. 3, pp. 232-240, 2006.

[58] V. Raghavendra, M. D. Rutkowski, and J. A. Deleo, "The role of spinal neuroimmune activation in morphine tolerance/hyperalgesia in neuropathic and sham-operated rats," Journal of Neuroscience, vol. 22, no. 22, pp. 9980-9989, 2002.

[59] V. Raghavendra, F. Tanga, and J. A. Deleo, "Inhibition of microglial activation attenuates the development but not existing hypersensitivity in a rat model of neuropathy," Journal of Pharmacology and Experimental Therapeutics, vol. 306, no. 2, pp. 624-630, 2003.

[60] C. Sommer, "Painful neuropathies," Current Opinion in Neurology, vol. 16, no. 5, pp. 623-628, 2003.

[61] L. R. Watkins and S. F. Maier, "Glia: a novel drug discovery target for clinical pain," Nature Reviews Drug Discovery, vol. 2, no. 12, pp. 973-985, 2003.

[62] J. Mika, M. Korostynski, D. Kaminska et al., "Interleukinlalpha has antiallodynic and antihyperalgesic activities in a rat neuropathic pain model," Pain, vol. 138, no. 3, pp. 587-597, 2008.

[63] S. B. McMahon, W. B. J. Cafferty, and F. Marchand, "Immune and glial cell factors as pain mediators and modulators," Experimental Neurology, vol. 192, no. 2, pp. 444-462, 2005.

[64] J. Mika, M. Osikowicz, E. Rojewska et al., "Differential activation of spinal microglial and astroglial cells in a mouse model of peripheral neuropathic pain," European Journal of Pharmacology, vol. 623, no. 1-3, pp. 65-72, 2009.

[65] A. K. Clark, E. A. Old, and M. M. Malcangio, "Neuropathic pain and cytokines: current perspectives," Journal of Pain Research, vol. 21, no. 6, pp. 803-814, 2013.

[66] F. Aloisi, "Immune function of microglia," GLIA, vol. 36, no. 2, pp. 165-179, 2001.

[67] F. J. P. M. Huygen, N. Ramdhani, A. Van Toorenenbergen, J. Klein, and F. J. Zijlstra, "Mast cells are involved in inflammatory reactions during Complex Regional Pain Syndrome type 1," Immunology Letters, vol. 91, no. 2-3, pp. 147-154, 2004.

[68] D. Irnich, D. J. Tracey, J. Polten, R. Burgstahler, and P. Grafe, "ATP stimulates peripheral axons in human, rat and mousedifferential involvement of $\mathrm{A} 2 \mathrm{~B}$ adenosine and $\mathrm{P} 2 \mathrm{X}$ purinergic receptors," Neuroscience, vol. 110, no. 1, pp. 123-129, 2002.

[69] J. M. Jimenez-Andrade, C. M. Peters, N. A. Mejia, J. R. Ghilardi, M. A. Kuskowski, and P. W. Mantyh, "Sensory neurons and their supporting cells located in the trigeminal, thoracic and lumbar ganglia differentially express markers of injury following intravenous administration of paclitaxel in the rat," Neuroscience Letters, vol. 405, no. 1-2, pp. 62-67, 2006.

[70] X. Jin and R. W. Gereau, "Acute p38-mediated modulation of tetrodotoxin-resistant sodium channels in mouse sensory neurons by tumor necrosis factor- $\alpha$, Journal of Neuroscience, vol. 26, no. 1, pp. 246-255, 2006.

[71] L. R. Watkins, M. R. Hutchinson, A. Ledeboer, J. WieselerFrank, E. D. Milligan, and S. F. Maier, "Glia as the "bad guys": implications for improving clinical pain control and the clinical utility of opioids," Brain, Behavior, and Immunity, vol. 21, no. 2, pp. 131-146, 2007.

[72] H. M. Wu, L. F. Zhang, P. S. Ding, Y. J. Liu, X. Wu, and J. N. Zhou, "Microglial activation mediates host neuronal survival induced by neural stem cells," Journal of Cellular and Molecular Medicine, vol. 18, no. 7, pp. 1300-1312, 2014. 
[73] G. B. Oliveira, A. Fontes Ede Jr., S. de Carvalho et al., "Minocycline mitigates motor impairments and cortical neuronal loss induced by focal ischemia in rats chronically exposed to ethanol during adolescence," Brain Research, vol. 1561, pp. 23-34, 2014.

[74] J. Mika, K. Popiolek-Barczyk, E. Rojewska, W. Makuch, K. Starowicz, and B. Przewlocka, "Delta-opioid receptor analgesia is independent of microglial activation in a rat model of neuropathic pain," PLoS One, vol. 9, pp. 1-9, 2014. 

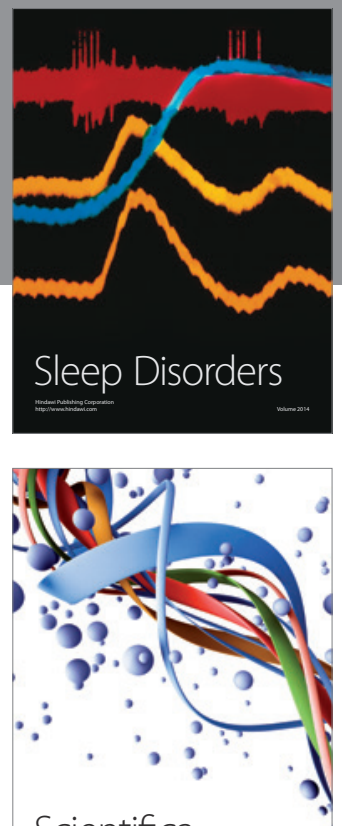

Scientifica
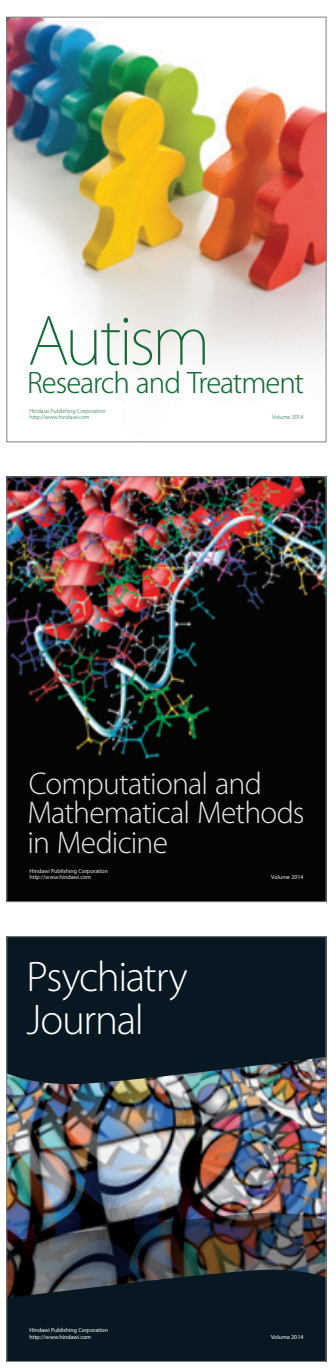
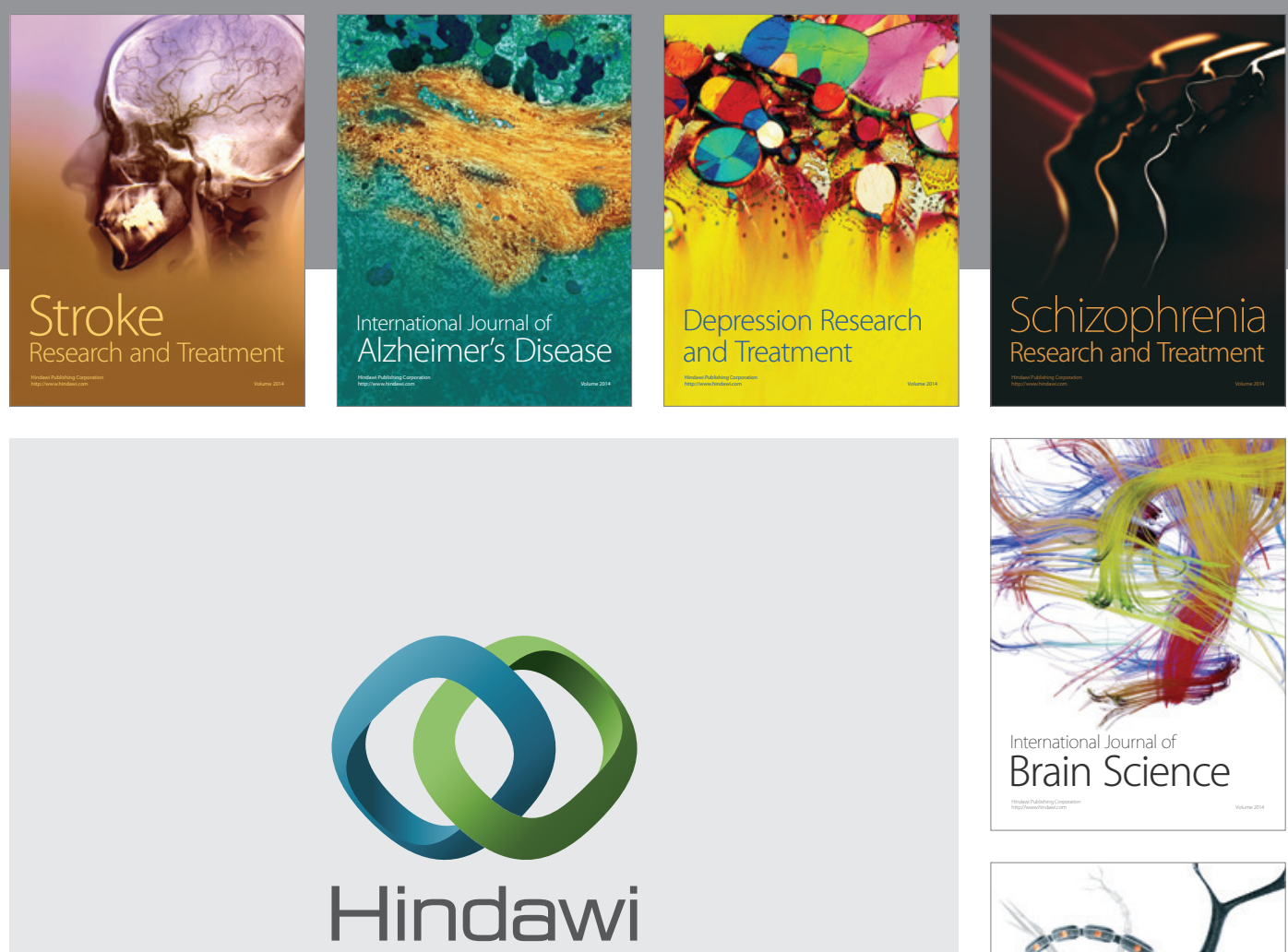

Submit your manuscripts at

http://www.hindawi.com
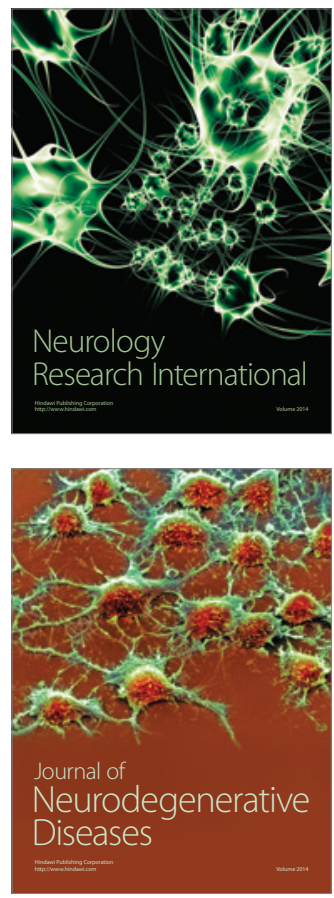

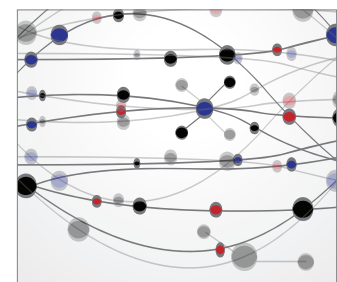

The Scientific World Journal
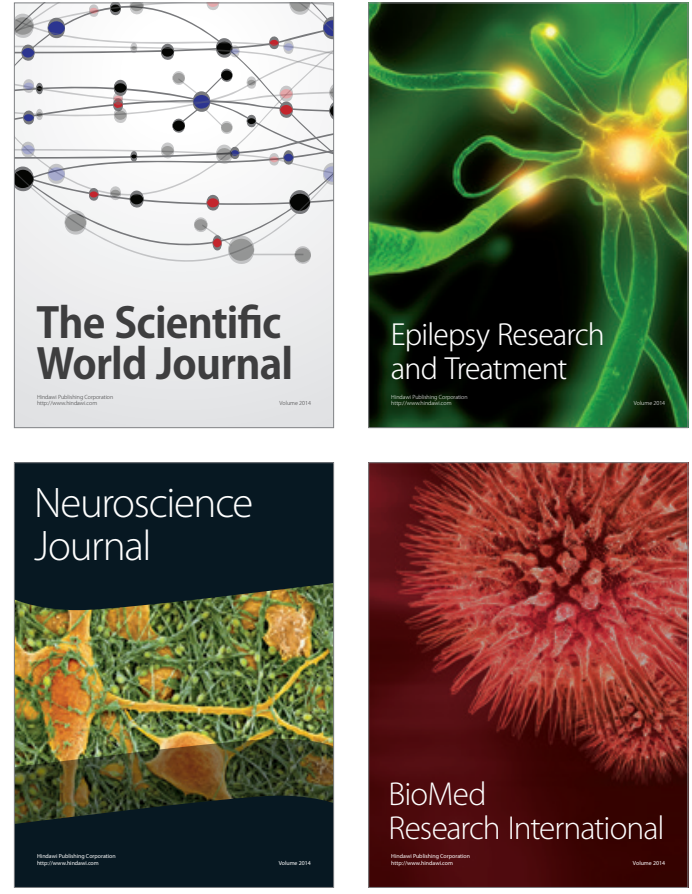

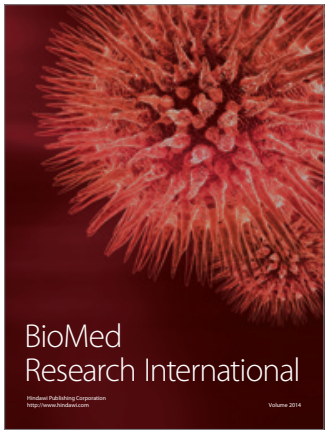

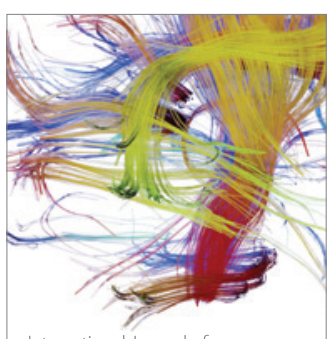

Brain Science

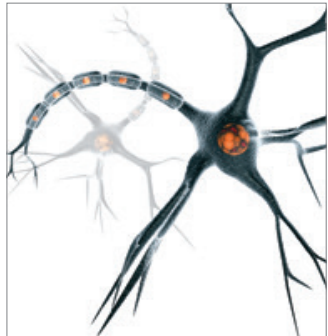

Neural Plasticity
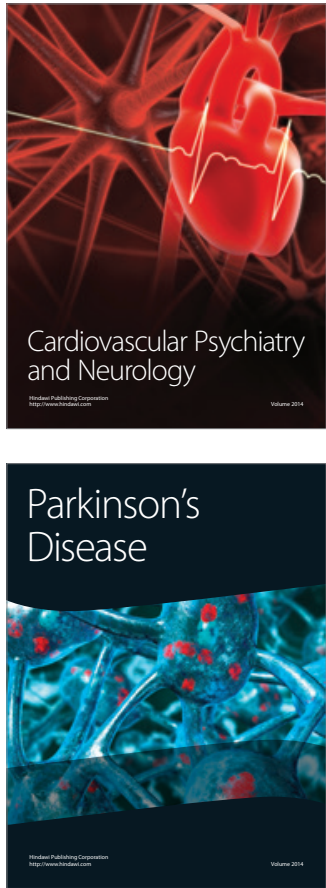